\title{
AGREEMENTS FOR SALE TO CORPORATIONS THE REMEDY OF EXTRA-JUDICIAL DETERMINATION
}

\author{
FRANCIS C.R. PRICE*
}

\begin{abstract}
A corporation which purchases land by agreement for sale does not receive the same protection under The Judicature Act as is accorded an individual. In particular, the vendor can exercise all the rights conferred by the agreement itself, including determining the agreement, keeping the land and often the money already paid. The courts, however, closely monitor the vendor's pursuit of his contractual remedies, and the proper steps must be followed to obtain the desired relief. In this article, the author draws together the law applicable to the prosecution of proceedings by the vendor for extrajudicial determination of an agreement for sale and also reviews some of the obstacles or defences that may be raised by the purchaser.
\end{abstract}

\section{INTRODUCTION}

Where land is sold to an individual purchaser, there is, from a practical point of view, little difference between a sale of the land pursuant to an agreement for sale and a sale of the land with a mortgage back to the vendor. In particular, as a result of provisions in The Judicature Act, ${ }^{1}$ notably s. 34 (17) and (18) and s. 32 (h) and (i), remedies that are available to the vendor or mortgagee are the same.

However, where the purchaser is a corporation, s. 35 of The Judicature Act provides that s. $32(\mathrm{~h})$ and (i) and s. $34(17)$ to (21) do not apply to the enforcement of the provisions of an agreement for sale, or mortgage given by that corporation. ${ }^{2}$

A common form of Agreement for Sale currently in use provides in part as follows:

IT IS AGREED that if the Purchaser shall make default in the payment of said purchase price, or interest thereon, or any part thereof on the days hereinbefore mentioned for the payment of the same, or makes default in the observance or performance of any of the covenants, conditions or provisions of this agreement, the times of payment aforesaid as well as the strict performance of each and every of the said other covenants, conditions and provisions of this agreement being conditions precedent, then and in either of such cases the Vendor, if he shall deem it advisable in the ex. ercise of an absolute and uncontrollable discretion so to do may at any time after the happening of any such default, DECLARE this agreement null and void as fully and completely as if this agreement had never been executed, by thirty (30) days' written notice to that effect served on the Purchaser or mailed in a registered letter addressed to him at his address above mentioned, and upon the expiration of the time limited in the said notice, the rights and interest hereby created or then existing in favour of the Purchaser, or derived under the provisions hereof, shall forthwith CEASE and DETERMINE without any legal proceedings being taken or other act being performed by or on behalf of the Vendor, and the lands herein mentioned shall REVERT TO and REVEST IN the Vendor and the Purchaser shall have no right to reclaim any moneys paid in respect of this agreement, and the same may be retained by the Vendor as liquidated damages.

* LL.B. (Hons.) (Melb.), LL.M. (Alta.), partner with the firm of Reynolds, Mirth \& Cote, Barristers and Solicitors, Edmonton, Alberta.

1. R.S.A. 1970 , c. 193.

2. Section 35 of The Judicature Act was amended to its present form in 1964 (S.A. 1964, c. 40, s. 4). From 1946 (S.A. 1946, c. 38) to 1964, the non-application of what are now s. 32(h) and (i) and s. 34 (17) to (21) was restricted to actions upon corporate debentures or trust deeds, or corporate mortgages in favour of the Industrial Development Bank. Prior to 1946 there was no exception of any kind. The requirement, incorporated in 1939 by S.A. 1939 , c. 85 , that there be a judicial sale in any action brought upon any mortgage or agreement for sale of land, meant that, until 1964, the possibility of extra-judicial determination disappeared. 
As will be seen, s. 35 of The Judicature Act enables the parties to the agreement for sale to exercise the rights that have been contractually agreed upon under such agreement. There are a number of substantial advantages to the use of the contractually agreed remedies. These include determination of the agreement for sale on the thirty (30) days' written notice agreed upon, retention by the vendor of moneys paid as liquidated damages, reversion to the vendor of all the interest in the land (particularly valuable in times of rising land prices, when the land may be resold at a profit), and avoidance of the lengthy foreclosure process with its order for specific performance and advertising.

However, exercise of the vendor's contractual rights has traditionally been closely monitored by the courts of equity, and awareness of the controls exercised by the courts is essential to the successful prosecution of an action involving determination of the agreement.

\section{NATURE OF PURCHASER'S RIGHTS UNDER AGREEMENT FOR SALE}

On executing the agreement for sale and making any initial payments stipulated, the purchaser immediately acquires an equitable interest in the property. ${ }^{3}$ The purchaser acquires this interest in the land notwithstanding lack of registration under The Land Titles Act. ${ }^{4}$

As long as the conditions of the agreement for sale are carried out, the vendor is only entitled to the purchase money stipulated under the agreement. The purchaser, on completing the payments required by the agreement, has the right to demand a conveyance of the title to the land.

However, it is clear that the interest which the purchaser acquires is only commensurate with the relief equity will give by way of specific performance. ${ }^{5}$ If, for some reason, specific performance is not granted, the purchaser's interest in the land no longer exists. ${ }^{6}$

\section{DETERMINATION OR RESCISSION}

Before proceeding further, a distinction should be made between "determination" or "cancellation" of the agreement on the one hand, and "rescission" on the other. This distinction was most clearly made by the Saskatchewan Court of Appeal in Orr v. Cook. ${ }^{7}$

With great deference I think the learned Judge was wrong in holding that said order nisi was rescission of the agreement. It was, in my opinion, a determination of the agreement, the results of which are very different from rescission. Rescission can only take place where there can be restitutio in integrum, and such is the result of rescission. The vendor gets back his land and the purchaser his purchase-money, except as a rule, the deposit. But in the case of determination of the agreement, the vendor generally retains the purchase-money paid, and takes back the property as well. The right to retain the purchase-money on determination is generally provided for by the agreement, as is the case in the case at bar.

3. In re Church [1923] 3 W.W.R. 405, 408.

4. Id, Jellett v. Wilkie (1896) 26 S.C.R. 282.

5. In re Church, supra, at 409; Howard v. Miller [1915] A.C. 318, 327.

6. Kimniak v. Anderson (1928) 63 O.L.R. 428, 434; Central Trust and Safe Deposit Co. v. Snider [1916] 1 A.C. 266, 272; DiGuilo v. Boland [1958] O.R. 384.

7. [1922] 3 W.W.R. 1153, 1155. See also Cowie v. McDonald [1917] 2 W.W.R. 356, 362. 
Their Lordships then referred to McCaul, Notes on the Remedies of Vendors and Purchasers of Real Estate, ${ }^{8}$ where the learned author states: ${ }^{9}$

"Rescission" then, which results from the disaffirmance of the contract is to be carefully distinguished from "determination" where.the vendor is not disaffirming, but expressly standing on the contract, and basing his rights upon its express or implied terms, covenants and conditions.

\section{JUDICIAL DECLARATION THAT AGREEMENT VALIDLY DETERMINED}

Where the agreement for sale gives the vendor, upon default by the purchaser, the right to determine the agreement, then, following such notice, an action will lie for a declaration by the court that the agreement has been properly determined, and that the agreement no longer affects the vendor's title. ${ }^{10}$

\section{In Moore v. Stewart, Lamont J. stated: ${ }^{11}$}

A valid cancellation of an agreement for sale of land pursuant to a clause therein which permits a vendor, upon default, to cancel the agreement and retain the moneys paid, carries with it certain consequences both to the vendor and the purchaser. The vendor, having put an end to the contract, cannot sue for the purchase money nor is he entitled to ask the Court to determine the contract, he having determined it himself. He is, in my opinion, as I held in Wilson v. Abbott, entitled to an order declaring that he had validly determined the contract, and that it therefore no longer affected his title.

However, the vendor may wish to apply for rescission of the contract, in the event of doubt as to the validity of his determination of the agreement. ${ }^{12}$

While in some cases there may be no pressing need for a judicial declaration that the agreement has been validly determined, such a declaration does have the advantage of providing to the vendor certainty of title to the land.$^{13}$ This is important in situations where the purchaser may at a later date make application to the court for relief against forfeiture resulting from his default; and it is essential in Alberta, where the purchaser's right to statutory relief under s. 19 of The Judicature Act appears to continue to exist until a "judgment" of the court. ${ }^{14}$ In addition, an order of the court is indispensable to extinguish the rights of holders of subsequent interests in the land claiming through the purchaser,

8. 1915, 2nd ed.

9. Id. at 63. See also Zimmer v. Karst (1910) 15 W.L.R. 58, 64; Milos v. Schmidt [1923] 3 W.W.R. 1278, 1280; Primeau and Imperial Lumber Yards Ltd. v. Meagher [1923] 3 W.W.R. 1308, 1312.

10. Wilson v. Abbott (1914) 6 W.W.R. 1097; Moore v. Stewart (1914) 7 W.W.R.991, 993.

11. Id at 993. There may of course be cases where the wording of the agreement is such that judicial determination is required: see Spetch v. Bingaman (1953) 8 W.W.R. 315, where the agreement included a covenant by the purchaser that he would on default execute an assignment of the agreement back to the vendor. Upon the purchaser's refusal, the Supreme Court of British Columbia declared the agreement determined and the purchase money and improvements forfeited to the vendor.

12. Moore v. Stewart, supra n. 10 at 993.

13. In Wilson v. Abbott supra n. 10 at 1099, Lamont J. stated:

I can however see that where the land has been purchased under an agreement of sale, which agreement provides for its determination under certain conditions, a declaratory judgment that the agreement has been duly determined may be a convenient way of placing beyond dispute the question whether or not it still attaches to the vendor's title.

14. See part XII, infra. 
especially where the agreement for sale and subsequent interests have been registered against the title.

\section{EXTRA-JUDICIAL DETERMINATION}

\section{A. Preliminary Requirements}

Certain conditions must exist before the vendor can properly determine the agreement for sale. Obviously, the purchaser must be in default, so that the provisions for the determination of the agreement can take effect. Equally obviously, the vendor must not have waived his right to determine the contract. ${ }^{15}$

In addition, however, the vendor himself cannot be in default of any duty under the contract to the purchaser. ${ }^{16}$ Thus, where a vendor refused to produce title, the purchaser was excused for non-payment within the time specified, although time was of the essence of the agreement, and was awarded specific performance. ${ }^{17}$

In cases where the vendor himself is purchasing the land and making his title under a prior agreement for sale, then, where the vendor is in default under the prior agreement, he cannot penalize the purchaser for non-payment of the purchase money. ${ }^{18}$ However, where the default by the vendor is caused by default of the purchaser, the vendor will not be barred from exercising his rights under his agreement for sale. ${ }^{19}$

\section{B. Notice of Default/Determination}

The standard clause from the agreement for sale already referred to requires some form of written notice to be given to the purchaser of the vendor's intention to determine the agreement for sale. To be effective such notice of determination of the agreement must comply strictly with the clause in the agreement providing for such determination by the vendor. Failure to comply strictly has been held by the courts to be fatal to the validity of the notice. The onus of proving that there has been strict compliance with the contractual requirements is on the vendor, ${ }^{20}$ even though the purchaser does not object to the form of notice in his pleadings. ${ }^{21}$

Examples of defective notices given to purchasers can be found in the following cases. (1) Where the vendor is a company, notice cannot automatically be given by a subordinate officer of that company. ${ }^{22}(2)$ The notice will not be effective if it has not been given by all the vendors contained in the agreement. ${ }^{23}(3)$ The notice must be given to every one of the purchasers ${ }^{24}(4)$ The notice will be defective if it incorrectly recites the terms of the contract as to mode of determination, ${ }^{25}$ or the rate of

15. Timmins v. Smith (1910) 14 W.L.R. 503.

16. Newberry v. Langan (1912) 47 S.C.R. 114.

17. Id. See also Simson v. Young (1918) 56 S.C.R. 388.

18. Douglas v. Sharpe [1917] 2 W.W.R. 117; Bourne v. Phillips (1913) 4 W.W.R. 431.

19. Lebel v.Dobbie [1919] 2 W.W.R. 483, affd. [1920] 1 W.W.R. 818; Robson v. Wride (1868) 15 Grant 111.

20. Brown v.Roberts (1912) 1 W.W.R. 987, 988.

21. Id.

22. Pitt River Lumber Co. v. Shaake (1914) 6 W.W.R. 994.

23. Id.

24. Bark Fong v. Cooper (1913) 49 S.C.R. 14, where the purchasers were in fact partners.

25. March Bros. and Wells v. Banton (1911) 45 S.C.R. 338, 1 W.W.R. 544, 546. 
interest. ${ }^{28}(5)$ The notice will be invalid if it treats several contracts as one and demands the total amount due under all of them. ${ }^{27}(6)$ Where the agreement requires a notice intimating the vendor's intention of determining the agreement, there are conflicting decisions (based primarily on their facts) as to whether a notice purporting to determine the agreement thereby in fact complies with the terms of the agreement. ${ }^{28}(7)$ Where the agreement for sale stipulates that a demand must be made for payment, a notice of determination given to the purchaser which does not contain an express demand for payment, or which contains a demand for payment of more than what in fact was payable, will be invalid. ${ }^{29}(8)$ It has even been held that an inaccurate reference to the date of the agreement for sale in the notice of determination is sufficient to invalidate such notice. ${ }^{30}(9)$ The notice will be invalid if it allows the purchaser less time for payment or for remedy of his default than the agreement provides. ${ }^{31}(10)$ Where the agreement requires notice to be given to the purchaser in absolute terms a conditional notice will be invalid. ${ }^{32}(11)$ Where the form of the notice is set out in the agreement, a notice which merely says that in the event of continued default "proceedings for foreclosure will follow" will be invalid. ${ }^{33}(12)$ Where a notice of determination is sent to the purchaser in an envelope marked "private" and where such notice is given in such manner as to give it little chance to actually reach the purchaser, such notice is not valid. ${ }^{34}$ (13) A notice given by mail will be ineffective when the agreement stipulates personal delivery. ${ }^{35}$

\section{Effect of Defective Notice}

A notice of determination, which fails to be effective by reason of noncompliance with the provisions of the agreement for sale, may nevertheless be important to make it clear that the vendor is not acquiescing in the purchaser's default, but is insisting on strict performance. ${ }^{36}$

However, if the vendor gives a notice of determination of the agreement for sale which is defective or invalid, this may operate as a rescission or repudiation of the contract, entitling the purchaser to recover all payments made to the vendor and possibly damages for wrongful

26. Brown v. Roberts, supra n. 20.

27. Stewart v. Borm (1911) 19 W.L.R. 166.

28. Compare Canadian Fairbanks Co. v.Johnston (1909) 10 W.L.R. 571 and Price v.Ruggles [1917]2 W.W.R. 1035 with Steele v.McCarthy (1908) 7 W.L.R.902 and Timmins v.Smith (1910) 14 W.L.R. 503.

29. Great West Lumber Co. v. Wilkins (1907) 7 W.L.R. 166, 170.

30. Id.

31. Le Neveu v. McQuarrie (1907) 5 W.L.R. 348; followed in Fox v.Reid(1913) 4 W.W.R.200, where 30 days notice was provided instead of the one month stipulated by the agreement.

32. Constantino v. Dick (1913) 5 W.W.R. 1319, where the agreement provided "it may be declared void by notice to that effect", while the notice said that unless payment were made it would be considered void.

33. Brown v. Roberts, supra n. 20.

34. Mills v. Marriott (1912) 3 W.W.R. 841, 844.

35. Bark Fong v. Cooper, supra n. 24.

36. Hicks v. Laidlaw (1912) 1 W.W.R. 1008. 
repudiation. ${ }^{37}$ In addition the purchaser may also recover for improvements made to the land, where these improvements were contemplated by both parties at the time the agreement for sale was executed. ${ }^{38}$

However, a defective notice of determination by the vendor will not necessarily prevent the vendor from suing for the outstanding purchase price. ${ }^{39}$

\section{Pleadings as Written Notice}

Normally the notice of determination will be provided in writing to the purchaser prior to the commencement of any action by the vendor. However, it has been held that the pleadings themselves may provide the appropriate written notice under the agreement for sale..$^{40}$

\section{WAIVER BY VENDOR}

If the vendor does any acts inconsistent with the position that the agreement is at an end, he will waive his right to determine the agreement. This principle is equally applicable to rescission by either the vendor or the purchaser. In Labelle v. O'Connor, Anglin J. stated:41

There can be no doubt that by doing any act, after the default, which involves or implies the continued existence of the contract, the party entitled to rescind waives such rights. He may lose his right as well by acquiescing in the defaulter assuming a position consistent only with the subsistence of the contract.

In Dunlop v. Bolster, ${ }^{42}$ Walsh J., delivering judgment for the Alberta Supreme Court en banc, pointed out that the purchaser could not have disputed the right of the vendor to determine the agreement (because of the purchaser's abandonment of the agreement) if the vendor had not already commenced an action for specific performance and payment of the whole of the purchase money. This commencement of such an action waived the vendor's rights to determine the contract.

In Diamond v. Western Realty Company, ${ }^{43}$ the agreement provided that if the purchaser did not sell a certain number of lots within a specified time, the vendor could determine the agreement. However, the vendor demanded from the purchaser an accounting for lots sold after the specified deadline and accordingly was held to have waived his rights to determine the contract.

37. March Bros. and Wells v. Banton (1911) 45 S.C.R. 338 (purchase money); Muirhead v. Atkin [1920] 2 W.W.R. 228 (damages - difference between the market value and the purchase price).

38. Mitchell v. Wilson (1912) 20 W.L.R. 671.

39. Pitt River Lumber Co. v. Shaake, supra n. 22.

40. See Price v. Parsons (1913) 5 W.W.R. 199, 200 (statement of claim good notice to the defendant of the exercise of the option to accelerate the whole of the purchase money due); Reeve v. Mullen (1913) 5 W.W.R. 129 (commencement of action sufficient notice of the purchaser's intention to rescind the contract on the ground of the vendor's failure to show title); Smith v. Crawford [1918] 2 W.W.R. 298, 303 (allegation in statement of defence held to constitute a repudiation of the agreement); Glover v. Smith [1931] 40 0.W.N. 78, 81 (writ held sufficient notice).

41. (1908) 15 O.L.R. 519, 547. See also Crawley v. Hamley (1909) 11 W.L.R. 574; Timmins v. Smith (1910) 14 W.L.R. 503.

42. (1912) 2 W.W.R. 550.

43. (1919) 58 S.C.R. 620. 
Where the purchase price is payable by instalments and there is a power to determine the agreement on default in payment, the receipt by the vendor of a subsequent instalment is a waiver of the right to determine in respect of a previous default. However, there is some doubt as to whether acceptance of an instalment which is due prior to the actual determination of the agreement, but is received by the vendor after the determination, must necessarily be deemed to be a waiver of the determination. In Chadwick v. Stuckey, Harvey C.J., delivering the judgment of the court, stated: ${ }^{44}$

It would appear from this [acceptance of money on an overdue instalment] that the defendant may in fact have waived his right to consider time of the essence in respect of this instalment; I do not rely on this view, but it does appear to me that it would be most inequitable to permit the defendant to receive the money which would only be paid on the supposition that the defendant was not insisting on his right to cancel, and then immediately, or as soon as he saw fit, to cancel the agreement in respect of the default.

His Lordship cited Hunter v. Daniel ${ }^{45}$ which had previously been cited in Forfar v.Sage $e^{46}$ as authority for the equating of such actions with a waiver of the right to determine the agreement.

To the contrary, it was held in Massey v. Walker ${ }^{47}$ that the vendor's acceptance of part of the purchase money, which the purchaser paid before the notice of determination was served, did not amount to a waiver of the default.

Finally, if a subsequent default occurs, the receipt of money by the vendor, although amounting to a waiver of the right to determine in respect of the previous default, will not prevent a new right of determination or rescission from arising. ${ }^{48}$

\section{A. Inconsistent Remedies}

\section{ELECTION OF REMEDY}

Under a typical agreement for sale the vendor and the purchaser have a number of remedies available to them. Some of these remedies will be inconsistent since some may rely on the affirmance of the contract (such as determination and specific performance actions), while some depend on a disaffirmance of the contract (such as rescission).

Where the vendor is entitled to inconsistent remedies he must make an election between them, and this election once made is in general irrevocable. In Standard Trust Co. v. Little, ${ }^{49}$ the Saskatchewan Supreme Court en banc quoted from the case of Zimmerman v. Robinson. ${ }^{50}$

Let us first consider what is meant in law by "an election of remedies". It not infrequently happens that for the redress of a given wrong, or the enforcement of a given right, the law affords two or more remedies. Where these remedies are so inconsistent that the pursuit of one necessarily involves or implies the negation of the other, the party who deliberately and with full knowledge of the facts, invokes one of such remedies, is said to have made his election, and cannot, thereafter, have the benefit of the other.

44. (1912) 3 W.W.R. 549, 557.

45. (1845) 4 Hare 420, 67 E.R. 712.

46. (1902) 5 Terr. L.R. 255.

47. (1913) 4 W.W.R. 557.

48. Forfar v. Sage (1902) 5 Terr. L.R. 255.

49. (1915) 8 W.W.R. 1112, 1118.

50. 128 Iowa 72 . 
Where a purchaser demands the return of the purchase money paid under an agreement for sale, such demand is an irrevocable election which prevents him from subsequently claiming specific performance of the agreement. ${ }^{51}$ Similarly, a vendor cannot recover the purchase price or enforce a judgment recovered by him for the purchase price (except as to costs) where he has effected an extra-judicial determination of the agreement. ${ }^{52}$

If the vendor is in a position to rescind or determine the agreement for sale because of the purchaser's default and nevertheless sues for specific performance of the contract, he cannot, after such election, resist a counterclaim by the purchaser for specific performance of the agreement. ${ }^{53}$

However, nothing prevents a vendor from pursuing remedies which are not inconsistent with each other. Thus, where a vendor has given a purchaser notice of determination pursuant to the provisions of an agreement, such notice will not prevent the vendor from suing the purchaser for foreclosure or for judicial cancellation of the contract based on the same default. ${ }^{54}$

It is clear that inconsistent remedies or forms of relief may properly be claimed in the parties' pleadings as alternatives, but the facts pleaded must support the cause of action. ${ }^{55}$

\section{B. Time of Election}

At what time during the course of court action on an agreement for sale will the party or parties be deemed to have made their election irrevocably?

The decision of the Saskatchewan Court of Appeal in Standard Trust Co. v. Little indicates at one point that "the time to make his election is generally when he asks for his judgment or other". ${ }^{56}$ This statement would appear to require the party to make his election when he sets the matter down for hearing by the court by filing his Notice of Motion.

However in that case it was also stated that "the taking out of the order ... by the Plaintiffs was an election upon their part to rescind the contract if the Defendants did not pay within the time prescribed". ${ }^{57}$

In Davidson v. Sharpe, Anglin J. stated: ${ }^{58}$

When the vendor sought and obtained a judgment fixing a period for payment and providing that on default the agreement shall be cancelled and at an end and all moneys paid thereunder forfeited to the Plaintiff, he elected in my opinion, on that event happening to take the property in satisfaction of so much of the purchase money as then remained unpaid.

51. McDougall v. Allen (1922) 55 N.S.R. 278, 65 D.L.R. 320, 322.

52. Davidson v. Sharpe (1920) 60 S.C.R. 72, 85.

53. Dunlop v. Bolster (1912) 2 W.W.R. 550.

54. Kum Jow v. Elliott [1921] 1 W.W.R. 785.

55. Pitt River Lumber Co. v. Shaake, supra n. 22. Standard Trust Co. v. Little (1915) 8 W.W.R.1112, 1116; Elliott v.Barry[1920]2 W.W.R.478; Hole v. Wilson(1911)16 W.L.R. 352; Lee v. Sheer (1914) 7 W.W.R.927; Regina Brokerage and Inv. Co. v. Waddell (1916) 10 W.W.R. 364; Dobson v. Winton \& Robbins Ltd. [1959] S.C.R. 775, 779. Scott Bros. Gravel Co. Ltd. v. N.W. Hullah Corporation Ltd. (1967) 59 W.W.R. 173.

56. (1915) 8 W.W.R. 1112 at 1116.

57. Id at 1117.

58. (1920) 60 S.C.R. 72, 83. 
In Primeau and Imperial Lumber Yards $L t d$. v. Meagher, ${ }^{59}$ the Saskatchewan Court of Appeal held that the time at which the election occurred was when the vendor took out the order nisi for cancellation of an agreement for sale. In Diewold v. Diewold ${ }^{60}$ the Supreme Court of Canada agreed with this approach and found the time at which the election occurred was the time when the party in question took out the judgment. ${ }^{61}$

From these cases it would seem that when the vendor applies to the court for a particular remedy and, having obtained such remedy, files the order granted by the court, he has then made his election as to the nature of his remedy and cannot change his mind.

\section{PURCHASER'S RELIEF}

Assuming that the vendor has properly determined the contract, and further assuming that the purchaser either makes no appearance or does not dispute the vendor's claim, the vendor should have no problem establishing his right to the remedies agreed upon pursuant to the contract between the vendor and the purchaser. At law, the vendor was entitled to stand upon his strict rights pursuant to the contract. These included the right to determine the contract with or without notice, depending upon its terms, and to retain all moneys that the contract stipulated should be retained by the vendor in the event of default by the purchaser and determination of the contract. The purchaser's protection arises under the equitable jurisdiction of the court. Accordingly, if the purchaser does not seek to invoke this equitable jurisdiction or does not appear, the maxim "equity follows the law" will presumably have full application, and the vendor will obtain everything to which he is entitled under the agreement for sale.

If the purchaser wishes to retain his rights to the land or to the purchase money or both, it is incumbent upon him to make application to the court to show why the court's equitable jurisdiction should be exercised in his favour, or why he is otherwise entitled to relief.

A distinction has been drawn by the courts between the purchaser's rights to invoke the equitable jurisdiction of the court with respect to forfeiture of his interest in the land, and, on the other hand, his rights to the refund of all or a portion of the purchase moneys already paid to the vendor.

In Drinkle v. Steedman ${ }^{62}$ the agreement for sale contained the provision that if the purchaser defaulted in any of the payments to be made, the vendor should be at liberty, without notice, to cancel the agreement and declare it void, and to retain any payments made on account of it as liquidated damages, and to retain all improvements made on the premises, or else to proceed to another sale, with any deficiency in price, plus costs, charges and expenses to be borne by the purchaser. It was also provided that time was to be considered of the essence of the agreement. The down payment had been made at the time of execution of the agreement. However, the first instalment was not paid on time. The vendor

59. [1923] 3 W.W.R. 1308, 1310.

60. [1941] S.C.R. 35, 38.

61. See also Dobson v. Winton \& Robbins Ltd. [1959] S.C.R. 775, 779.

62. (1915) 9 W.W.R. 1146. 
gave notice cancelling the agreement. The purchaser, immediately upon receipt of such notice, tendered the full amount due together with interest thereon. The vendor refused to accept it.

The Saskatchewan Court of Appeal ${ }^{63}$ not only granted the purchaser relief from forfeiture of the moneys paid under the agreement, but also decreed specific performance of the agreement. On further appeal, the Privy Council stated as follows: ${ }^{64}$

As to the relief from forfeiture, their Lordships think that the Supreme Court were right in holding, for the reasons assigned in the former decision of this Board [Kilmer v. B.C. Orchard Lands $L t d$.] that the stipulation in question was one for a penalty, against which relief should be given on proper terms. But as regards specific performance they are of the opinion that the Supreme Court were wrong in reversing Mr. Justice Newlands' judgment. Courts of Equity, which look at the substance as distinguished from the letter of agreements, no doubt exercise an extensive jurisdiction which enables them to decree specific performance in cases where justice requires it, even though literal terms of stipulations as to time have not been observed. But they never exercised this jurisdiction where the parties have expressly intimated in their agreement that it is not to apply, by providing that time is to be of the essence of their bargain.

Their Lordships accordingly refused to grant specific performance, so that the purchaser lost any interest that he might have had in the lands themselves. However, their Lordships referred the matter back to the Saskatchewan courts to determine how much money should be returned to the purchaser.

In Alberta, the equitable jurisdiction of the court has been replaced by a statutory jurisdiction under s. 19 of The Judicature Act in those cases where the breach of covenant or non-payment of moneys due under the agreement for sale has been remedied or paid together with costs before any judgment is recovered. Where the purchaser's default is remedied before the matter comes to court, the court does not have any discretion in the matter. It must grant the appropriate relief. ${ }^{65}$

However, where the parties come to court, and the purchaser is unable or unwilling to remedy the breach of covenants or to pay all the arrears owing under the agreement for sale, then the purchaser can only rely on the equitable jurisdiction of the court, now embodied in s. 32(o) of The Judicature Act.

\section{DETERMINATION OF THE PURCHASER'S INTEREST IN THE LAND}

From the Drinkle v. Steedman case it appears that where the determination has been properly effected extra-judicially, then in cases where time has been agreed to be of the essence of the contract and such provision has not been waived by the vendor, there is no equitable jurisdiction to relieve against such determination insofar as the interest of the purchaser in the land is concerned..$^{68}$

63. Following Kilmer v. B.C. Orchard Lands Ltd. [1913] A.C. 319.

64. (1915) 9 W.W.R. 1146, 1148, quoted and followed by Miller, J. in Centurian Ridge Farms Ltd. v. McCallum Estate (1978) 14 A.R. 391, 401.

65. See part XII, infra.

66. See also Brickles v.Snell [1917]1 W.W.R.1059 (P.C.); Steele v.McCarthy (1908) 7 W.L.R. 902; although now this approach must be queried in light of the obiter reference to Drinkle v. Steedman by Stevenson J.A. in $A \& M$ Developments Ltd. v. City of Edmonton (May 1981) unreported, Alta. C.A., Appeal No. 13938 (Edmonton). 
Where the purchaser does default, his interest in the land is gone and any caveat that may have been registered to protect such interest is removable. ${ }^{67}$

However in some cases the agreement will not have made time of the essence, or, more commonly, time may originally have been of the essence but has been waived either expressly or by implication. In such circumstances it has been held that the equitable jurisdiction of the court to relieve against the forfeiture of the purchaser's interests in the land still exists. $^{68}$

\section{RELIEF AGAINST FORFEITURE OF PURCHASE MONEY PAID}

\section{A. When will relief be granted?}

Whether time is of the essence or not, there still remains equitable jurisdiction in the court to relieve the purchaser from the forfeiture of money paid under the agreement for sale, even though the contract contains an express provision allowing the vendor to retain the purchase money paid, and even though the agreement for sale has been determined in the exact manner prescribed by the contract. ${ }^{69}$

It has recently been held that where a vendor has terminated a contract by notice, the moneys paid under the contract by the purchaser are prima facie recoverable. ${ }^{70}$ This proposition is certainly correct in circumstances where the agreement for sale contains no forfeiture clause. ${ }^{71}$

However, where the agreement for sale contains a forfeiture clause, it is submitted that the courts no longer treat the instalments already paid as prima facie recoverable by a defaulting purchaser. It is clear that the defaulting purchaser has no right at law to recover these moneys paid. ${ }^{72}$ He may, however, have a right in equity to relief against forfeiture of the money, notwithstanding the express provisions of the agreement. The difficulty is to know what circumstances give rise to this equity.

67. Drinkle v.Steedman (1915) 9 W.W.R. 1146; Brickles v. Snell supra n. 66; McCullough v. C.P.R. [1920] 1 W.W.R. 663 .

68. Kilmer v. B.C. Orchard Lands $L$ td. [1913] A.C. 319, as explained in Drinkle v.Steedman (supral.

69. Drinkle v.Steedman (1915) 9 W.W.R.1146; Brickles v.Snell[1917]1 W.W.R. 1059; Chadwick v.Stuckey (1912) 3 W.W.R. 549; Great West Lumber Co. v. Wilkins (1907) 7 W.L.R. 166, 174; Re Dagenham (Thames) Dock Co. (1873) L.R. 8 Ch. App. 1022; City of Edmonton v. $A \& M$ Developments $L t d$ (1980, unreported Q.B. Action No.96352, per Belzil, J., affd. with variation (May 1981) unreported, Alta. C.A., Appeal No.13938(Edmonton) [see text infra at n. 123]). But see Stockloser v. Johnson [1954] 2 W.L.R. 439, 458, per Romer L.J., Mussen v. VanDieman's Land Co. [1938] Ch. 253 per Farwell J., and Galbraith v. Mitchenall Estates Ltd. [1964] 3 W.L.R. 454, 462 per Sachs J., where all three judges were of the opinion that, where a vendor has validly terminated an agreement, no equity exists in a purchaser to recover instalments of purchase money already paid.

70. Per Belzil J. in City of Edmonton v. A \& M Developments Ltd. (1980) unreported, Q.B. Action No.96352, citing March Bros. and Wells v. Banton (1911) 45 S.C.R. 338, 1 W.W.R. 544, Mayson v. Clouet [1924] 3 W.W.R.211, Rudd v.Balaz [1940]2 W.W.R. 107, although in the latter case Dysart J. (at p. 111) stated that, if the agreement so provides, the vendor is generally entitled to retain some or all of the money.

71. Stockloser v. Johnson [1954] 1 Q.B. 476, 2 W.L.R. 439, 448, 1 All E.R. 630 per Denning L.J., and the cases there cited.

72. Id. 
In the 1911 case of March Bros. \& Wells v. Banton, Idington J. stated: ${ }^{73}$

A purchaser who has never in fact abandoned or receded from his contract, but yet by reason of laches or otherwise, from causes not falling within abandonment or rescission, deprived himself of the right to specific performance is, in case the vendor refuse to accede to specific performance, prima facie entitled to a return of the deposit or part payment; unless some facts are shown that would render this inequitable.

This statement clearly imposed on the vendor the burden of showing that it would be inequitable for him to have to return the money he had already received..$^{74}$

\section{B. Approaches in Stockloser v. Johnson}

However, the approach adopted more recently by the English and Canadian courts appears to be the reverse of that taken in March Bros. \& Wells v. Banton ${ }^{75}$ and Drinkle v. Steedman ${ }^{76}$ This recent approach to the problem of relief against forfeiture or penalties stems from the decision of the English Court of Appeal in Stockloser v. Johnson. ${ }^{77}$ In that case a purchaser of quarrying machinery failed to make one of the required instalments under the agreement, and the vendor terminated the agreement and retained the instalments paid, as he was entitled to do pursuant to the agreement.

The Court of Appeal differed sharply in their opinions. Romer L.J. held $^{78}$ that the court could not intervene to grant relief unless there were some special circumstances such as fraud, sharp practice or other unconscionable conduct of the vendor. Somervell and Denning L.JJ. both felt that their equitable jurisdiction was not so restricted. There were, however, two requirements to be met before the equitable jurisdiction could be invoked ${ }^{79}$ First, the forfeiture clause must be of a penal nature, in the sense that the sum forfeited must be out of all proportion to the damage. Second, it must be unconscionable for the seller to retain the money. Denning L.J. explained the decision in Drinkle v. Steedman: ${ }^{80}$ "The basis of the decision ... was, I think, that the vendor had somewhat sharply exercised his right to rescind the contract and retake the land, and it was unconscionable for him also to forfeit the sums already paid."

Stockloser v. Johnson has been followed in Canada. In Popyk v. Western Savings and Loan Association, ${ }^{82}$ the Appellate Division of the Supreme Court of Alberta discussed the principles involved in the court's power to relieve against a forfeiture. Their Lordships cited s. 32(o) of The Judicature Act:

73. (1911) 45 S.C.R. 338, 343-4. It should be noted that this case dealt with a situation where the agreement had been rescinded as opposed to determined (see comments of Davies J., at 343 ). This may provide the true reason for the different approach of the Court to the return of the moneys paid, in order to achieve restitutio ad integrum.

74. See also the decision of Belzil J. in City of Edmonton v. A\& M Developments Ltd (1980), unreported, Q.B. Action No. 96352; affd. with variation (May 1981) unreported, Alta. C.A., Appeal No. 13938 (Edmonton).

75. (1911) 45 S.C.R. 338.

76. [1916] 1 A.C. 275, (1915) 9 W.W.R. 1146.

77. [1954] 1 Q.B. 476, 2 W.L.R. 439, 1 All E.R. 630.

78. [1954] 2 W.L.R. 439, 458.

79. Id at 443 (Somervell L.J.) and at 448 (Denning L.J.).

80. Supra n. 76.

81. Supra n. 78, at 449.

82. (1969) 67 W.W.R. 684 . 
32.(o) Subject to appeal as in other cases, the Court has power to relieve against all penalties and forfeitures and, in granting such relief, to impose such terms as to costs, expenses, damages, compensation and all other matters as the Court sees fit;

Their Lordships then referred to the case of Snider v. Harper, ${ }^{83}$ and held that s. 32(o) cannot be read with any restriction:

It [s. 32(0)] gives the Court power to relieve against all penalties and forfeitures. Where the contract provides for forfeiture, whether such forfeiture be provided for in express words or not, the Court has power to relieve against it.

The Court found that there was a forfeiture under the contract, and that the Court had the power to relieve against the forfeiture. They then had to determine whether they should in fact exercise this power to relieve against forfeiture.

Their Lordships referred to the statements of Somervell L.J. in Stockloser v. Johnson: "I am clear that the Plaintiff could only recover if he could satisfy the Court that it was unconscionable in the Defendant to retain the money". ${ }^{84}$

The Alberta Appellate Division continued: ${ }^{85}$

With the greatest of deference I agree with that statement. Why should a Court interfere with the terms of a contract unless the Plaintiff can demonstrate that it would be unconscionable for the Defendant to retain the moneys as provided for in the terms of the contract. Before a Court is justified in interfering it is not sufficient for a Plaintiff to show that the contract was improvident; he must show that the forfeiture was unconscionable.

In Dimensional Investments Ltd. v. The Queen, ${ }^{86}$ the Supreme Court of Canada considered Stockloser v. Johnson ${ }^{87}$ and compared the views of Romer L.J. with those of Somervell and Denning L.JJ.. Thurlow J. at trial had adopted the majority opinion, but the Supreme Court of Canada did not find it necessary to adopt either view because, even if the opinion of the majority in Stockloser were to prevail, it would not entitle the appellant to succeed in the case at bar.

Although no detailed examination has been made nor any preference stated for the opinion of either the majority or minority in Stockloser v. Johnson, the reported cases do indicate an unstated preference for the opinions of Somervell and Denning L.JJ. ${ }^{88}$ From these opinions it is clear that two questions must be considered. First of all, is the forfeiture clause a penalty? Secondly, is it "unconscionable" for the vendor to retain the payments made?

\section{C. "Penalty"}

The first question involves a comparison between a penalty and a genuine pre-estimate of damages. In Stockloser v. Johnson, ${ }^{89}$ Dimen-

83. [1922] 2 W.W.R. 417.

84. [1954] 1 Q.B. 476, 2 W.L.R. 439, 1 All E.R. $630,634$.

85. Supra n. 82 at 692.

86. (1967) 64 D.L.R. (2d) 632, 636.

87. Although this portion of their decision was clearly obiter: id. at 635.

88. See Popyk v. Western Savings and Loan Association (1969) 67 W.W.R. 684 (Alta. A.D.); Hughes v. Lukuvka (1970) 75 W.W.R. 464 (B.C.C.A.); Craig v. Mohawk Metal Ltd. (1975) 9 O.R. (2d) 716 (Ont. H.C.). It is important to note that these cases do not appear to have been referred to by counsel or the court in City of Edmonton v. A\& M Developments Ltd. (1980) unreported, Belzil J., Q.B. Action No. 96352.

89. Supra n. 77. 
sional Investments $L t d$. v. The Queen, ${ }^{90}$ Hughes v. Lukuvka ${ }^{91}$ and Craig v. Mohawk Metal Ltd., ${ }^{92}$ the courts found that the forfeiture clause did not effect a penalty, so that no relief was granted.

The locus classicus as to when a provision will be held to be a penalty is found in the judgment of Lord Dunedin in Dunlop Pneumatic Tyre Co. Ltd. v. New Garage \& Motor Co. Ltd.: ${ }^{93}$

1. Though the parties to a contract who use the words "penalty" or "liquidated damages" may prima facie be supposed to mean what they say, yet the expression used is not conclusive. The Court must find out whether the payment stipulated is in truth a penalty or liquidated damages. This doctrine may be said to be found passim in nearly every case.

2. The essence of a penalty is a payment of money stipulated as in terrorem of the offending party; the essence of liquidated damages is a genuine covenanted pre-estimate of damage IClydebank Engineering and Shipbuilding Co. v. Don Jose Ramos Yzquierdo y Castaneda, [1905] A.C. 6).

3. The question whether a sum stipulated is penalty or liquidated damages is a question of construction to be decided upon the terms and inherent circumstances of each particular contract, judged of as at the time of the making of the contract, not as the time of the breach (Public Works Commissioner v. Hills, [1906] A.C. 368, and Webster v. Bosanquet, [1912] A.C. 394).

4. To assist this task of construction various tests have been suggested, which if applicable to the case under consideration may prove helpful, or even conclusive. Such are:

(a) It will be held to be penalty if the sum stipulated for is extravagant and unconscionable in amount in comparison with the greatest loss that could conceivably be proved to have followed from the breach. (Illustration given by Lord Halsbury in Clydebank Case, [1905] A.C. 6).

(b) It will be held to be a penalty if the breach consists only in not paying a sum of money, and the sum stipulated is a sum greater than the sum which ought to have been paid (Kemble v. Farrem 6 Bing. 141). This though one of the most ancient instances is truly a corollary to the last test. Whether it had its historical origin in the doctrine of the common law that when A. promised to pay B. a sum of money on a certain day and did not do so, B. could only recover the sum with, in certain cases, interest, but could never recover further damages for non-timeous payment, or whether it was a survival of the time when equity reformed unconscionable bargains merely because they were unconscionable, - a subject which much exercised Jessel M.R. in Wallis v. Smith, 21 Ch.C. 243 - is probably more interesting than material.

(c) There is a presumption (but no more) that it is penalty when "a single lump sum is made payable by way of compensation, on the occurrence of one or more or all of several events, some of which may occasion serious and others but trifling damage" (Lord Watson in Lord Elphinstone v. Monkland Iron and Coal Co., 11 App. Cas. 332).

On the other hand:

(d) It is no obstacle to the sum stipulated being a genuine pre-estimate of damages, that the consequences of the breach are such as to make precise pre-estimation almost an impossibility. On the contrary, that is just the situation when it is probable that pre-estimated damage was the true bargain between the parties /Clydebank Case, Lord Halsbury, [1905] A.C. at p. 11; Webster v. Bosanquet, Lord Mersey, [1912] A.C. at p. 398).

Reference should also be made to subsequent decisions. In Stockloser v. Johnson ${ }^{94}$ Denning L.J. made a distinction between cases where the vendor is attempting to exact a penalty or payment of an extravagant sum, and cases such as the case before his Lordship where the vendor only wanted to keep money which already belonged to him, which had been handed to him in part payment of the purchase price, and which, as soon as it was paid, belonged to him absolutely ${ }^{95}$ Denning L.J. continued that it

90. (1967) 64 D.L.R. (2d) 632.

91. (1970) 75 W.W.R. 464.

92. (1975) 9 O.R. (2d) 716.

93. [1915] A.C. 79, 86-88.

94. [1954] 2 W.L.R. 439, 447.

95. Cf. Hole v. Wilson (1909) 10 W.L.R. 145, 152, affd 16 W.L.R. 352. Steele v. McCarthy (1908) 7 W.L.R. 903, 908. See also the definition of "forfeiture" in Popyk v. Western Sav ings and Loan Association (1969) 67 W.W.R. 684, 689. 
was not a case of a seller seeking to enforce a penalty, but a buyer seeking restitution of money paid, so that different principles applied. One such principle appears to be that: The equity of restitution is to be tested ... not at the time of the contract, but by the conditions existing when it is invoked.

This approach is a departure from proposition No. 3 set out by Lord Dunedin in the Dunlop Pneumatic Tyre case, ${ }^{96}$ but it was also the requirement of Somervell L.J. in Stockloser v. Johnson ${ }^{97}$ that one looks at all the circumstances of a case and not just at the contract.

It is submitted that the correct approach is that taken by the Supreme Court of Canada in Dimensional Investments Ltd. v. The Queen:.98

Whether a provision in a contract is penal or not depends upon the construction of the contract, but the question of unconscionability must depend upon the circumstances of each case at the time when the clause is invoked.

\section{D. "Unconscionable"}

Even if the provision in question is penal in nature, it must also be unconscionable for the vendor to retain the money paid. ${ }^{99}$ In Dimensional Investments $L t d$. v. The Queen ${ }^{100}$ Ritchie J. referred to Bridge v. Campbell Discount Co. $L t d$., in which Lord Radcliffe stated: ${ }^{101}$

Even such masters of equity as Lord Eldon and Sir George Jessel, it must be remembered, were highly sceptical of the court's duty to apply the epithet "unconscionable" or its consequences to contracts made between persons of full age in circumstances that did not fall within the familiar categories of fraud, surprise, accident, etc., even though such contracts involved the payment of a larger sum of money on breach of an obligation to pay a smaller sum (see the latter's judgement in Wallis v. Smith (1882), 21 Ch. D. 243).

\section{and later, in the same case and at the same page:}

"Unconscionable" must not be taken to be a panacea for adjusting any contract between competent persons when it shows a rough edge to one side or the other, and equity lawyers are, I notice, sometimes both surprised and discomfited by the plenitude of jurisdiction, and the imprecision of rules that are attributed to "equity" by their more enthusiastic colleagues.

\section{In Stockloser v. Johnson Romer L.J. was of the opinion: ${ }^{102}$}

There is ... nothing inequitable per se in a vendor whose conduct is not open to criticism in other respects, insisting upon his contractual right to retain instalments of purchase-money already paid.

\section{and further stated:103}

... it seems to me that in the long run it is much better that people who freely negotiate and conclude a contract of sale should be held to their "bargain" rather than that the judges should intervene by substituting, each according to his own individual sense of fairness, terms which are contrary to those which the parties have agreed upon for themselves.

\section{E. Equitable nature of relief}

Because of the equitable nature of the relief claimed, apart from the problems of "unconscionability", the purchaser claiming such relief must

96. [1915] A.C. 79.

97. [1954] 2 W.L.R. 439, 447.

98. (1967) 64 D.L.R. (2d) 632, 638.

99. Id.

100. Id.

101. [1962] A.C. 600, 626. See also Popyk v. Western Savings and Loan Association (1969) 67 W.W.R. 684,692 (just because a contract is improvident does not mean that the forfeiture is unconscionable).

102. [1954]2 W.L.R. 439, 458.

103. Id. at 459 . 
always be mindful of the requirements of the courts of equity as preconditions to obtaining such relief. ${ }^{104}$

Accordingly, where the purchaser has expressly repudiated or abandoned the contract or is deemed to have done so, he will not be able to obtain any relief. ${ }^{105}$ Where the purchaser has been in default for an inexcusably long time, he may find himself barred by laches, even in circumstances where time is not stated to be of the essence of the contract. ${ }^{106}$ The purchaser cannot, while persisting in his default and refusing to perform his contract, have any relief under the equitable jurisdiction of the court. ${ }^{107}$ The purchaser should be prompt in seeking relief from forfeiture. ${ }^{108}$ The purchaser must also "come to court with clean hands." 109

\section{DEPOSIT OR INSTALMENT?}

While the purchaser may have a right to relief against forfeiture of the purchase money paid under an agreement for sale following determination of the same by the vendor, it is well settled that, where a deposit has been paid pursuant to the agreement, equity will not relieve against its forfeiture when the default is that of the purchaser. ${ }^{110}$

In James v. Hauf MacDonald J.A. reviewed the purpose of a deposit: ${ }^{11}$

A deposit is, in its primary purpose, a guarantee for the performance of the contract by the purchaser. If the purchase price is carried out, then the amount of the deposit is credited on the purchase price. If the contract comes to an end owing to default on the part of the purchaser, and this was the situation here, the purchaser cannot take advantage of his own default: see Howe v. Smith (1884) 27 Ch. D. 89 and Soper v. Armold (1889) 14 App. Cas. 429.

However in this context mention should be made of the Privy Council's decision in Brickles v. Snell. ${ }^{112}$ In that case the purchaser failed to close the transaction on the date stipulated, and the parties had agreed that time was to be strictly of the essence of the contract. Faced with these facts the Privy Council refused to grant the purchaser specific performance of the agreement, but granted relief against forfeiture of the money paid. The purchaser appears to have requested, for the first time before the Privy Council, relief against forfeiture of his deposit of $\$ 500.00$. Unfortunately this matter was disposed of by the Privy Council, not on the basis that the purchaser cannot recover a deposit (as opposed to an instalment) where the purchaser is in default, but on the basis that the claim for the recovery of the deposit had not been included in the purchaser's

104. See for example Hole v. Wilson (1911) 16 W.L.R. 352, 355, on the requirement that "he who seeks equity must do equity".

105. Fox v. Reid (1913) 4 W.W.R. 200; Edmonton Construction Co. Ltd. v. Maguire (1913) 4 W.W.R. 1062; Consolidated Investments Ltd. v.Acres [1917] 1 W.W.R. 1426; Chambers v. Merchants' Bank of Canada [1922] 1 W.W.R. 437; Yanik v. Conibear [1945] 1 W.W.R. 33, 39-42, citing Cornwall v. Henson[1900] $2 \mathrm{Ch} .298$.

106. Dalziel v. Homeseekers' Land Co. (1911) 18 W.L.R. 246, although see March Bros. \& Wells v. Banton (1911) 45 S.C.R. 338.

107. Oughton v. Osepreghy [1931] 1 W.W.R. 604; Gray v. Abbott [1923] 2 W.W.R. 424; Wallace v. Hesslein (1898) 29 S.C.R. 171, 174.

108. Moore v. Stewart (1914) 7 W.W.R. 991, 993.

109. Sanders v. Thomlinson (1910) 13 W.L.R. 121, 124, (breach of fiduciary duty between the parties).

110. De Palma v. Runnymede Iron \& Steel Co. [1950] O.R. 1, and authorities reviewed there; Hirst v. Moore (1954) 12 W.W.R. 609, 614; Cronholm v. Cole [1928] 3 D.L.R. 321, 322.

111. [1954] 1 D.L.R. 598, 601. See also Mayson v. Clouet [1924] 3 W.W.R. 211.

112. [1917] 1 W.W.R. 1059, [1916] 2 A.C. 599. 
pleadings. Lord Atkinson in fact stated that it was unfortunate that a claim had not been included for the return of the $\$ 500.00$ deposit, and appears to have been prepared to order the repayment of the deposit, even in a situation where the purchaser was found to be in default. However the comments of the Privy Council are certainly obiter dicta and do not appear to be in accord with the remaining decided cases on point.. ${ }^{113}$

The real difficulty arises in the consideration of whether or not a particular payment should be classified as a deposit or an instalment.

Whether money paid by the purchaser will be construed as a "deposit" or an "instalment" will depend on the terms of the contract itself and the intention of the parties as expressed in or to be implied from these terms. ${ }^{114}$. It has been held that for a payment to be construed as a deposit there should be something specifically stated in the agreement to that effect. ${ }^{115}$

Furthermore, whether a payment made is to be regarded as a deposit or an instalment will depend on the circumstances of each case. Thus, where the amount of the payment is large in comparison with the total purchase price, such a factor may result in the classification of the payment as an instalment. ${ }^{116}$ Where a payment is referred to as an instalment or as part of the purchase price (as opposed to a deposit) it will not prima facie be construed as a deposit. ${ }^{117}$

In Kowbel v. Marusiak, ${ }^{118}$ the Alberta Appellate Division had to consider circumstances where the purchaser had made default in paying the balance of the purchase price stipulated under the agreement, but had attempted to make the payment after the date stipulated. The Court held ${ }^{119}$ that the Appellant, although in default in making the payment, did not intend to repudiate the contract. After the purchaser's default, the vendor resold the land to a third party so that an action for specific performance of the contract was not possible. The purchaser sued for the recovery of the deposit and the Appellate Division held that the purchaser "had not acted so as to give the [vendor] the right to conclude that he had repudiated the contract and so free him to make the new sale as he did".

Ford J.A. ${ }^{120}$ referred to the decision of James v. Hauf. ${ }^{121}$ His Lordship reviewed the cases and stated that his interpretation of these authorities

113. Although see the comments of Mulock C.J.0. in Boericke v. Sinclair (1928) 63 O.L.R.237, 245, [1929] 1 D.L.R. 561.

114. March Bros. \& Wells v. Banton (1911) 45 S.C.R. 338.

115. Tavender v. Edwards (1908) 8 W.L.R. 308; Chambers v. Merchants' Bank of Canada [1922] 1 W.W.R. 437.

116. Skinner v. Shirkey (1908) 8 W.L.R. 56, 61; B.C. Orchard Lands Ltd. v. Kilmer (1912) 20 W.L.R. 892, 901 (B.C. C.A.); Mitchell v. Wilson (1912) 20 W.L.R. 671; McGreevy v. Hod$\operatorname{der}$ (1912) 8 D.L.R. 755; Hall v. Turnbull (1909) 10 W.L.R. 536.

117. Tavender v. Edwards (1908) 8 W.L.R. 308; March Bros. \& Wells v. Banton (1911) 45 S.C.R. 338. However, see Scott v. Butterfield [1951] 2 D.L.R. 339, where the money paid, although described on a receipt therefor as a part payment, was in fact a deposit and could be retained by the vendor. See also De Palma v. Runnymede Iron \& Steel Co. [1950] O.R. 1, where the money, although not described as either a part payment or a deposit, was found to be a deposit by the Court.

118. (1957) 21 W.W.R. 35.

119. Id at 37 .

120. Id. at 41.

121. [1954] 1 D.L.R. 598. 
was that, "if on the default of the purchaser the contract goes off, that is to say, if he repudiates the contract, then ... he can have no right to 'recover the deposit".

His Lordship continued: ${ }^{122}$

In my opinion, as I interpret the above and other authorities, it depends upon whether the default in meeting such payment and the conduct of the purchaser should be held to be a repudiation of the contract by him so as to entitle the vendor to treat it as at an end.

It is submitted, with respect, that this extends the relief that the courts are prepared to give to the defaulting purchaser substantially further than the previous authorities have done. It appears from the Kowbel decision that the court has to determine whether the purchaser's default is of such a nature as to amount to repudiation of the contract, thus ignoring the law and authorities relating to contracts where time is stated to be of the essence and ignoring the failure of the purchaser to abide by the deadlines set by such contracts. However, in City of Edmonton v. A. \& M. Developments $L t d,{ }^{123}$ Belzil J. held that the purchaser in that case was in default and the City had properly terminated the contract. The agreement provided for a payment of $\$ 191,000.00$ to be made upon the execution of the agreement. However, included in this $\$ 191,000.00$ were two payments for options granted by the City in the amount of $\$ 38,500.00$ each. The purchasers had paid for these options and had paid to the City the balance of the down payment. Belzil J. held that the portion paid by the purchaser for the option and for the extension of the option was not recoverable, but the balance of the down payment less the option money was recoverable. It is to be noted that the option moneys paid were to be applied on the purchase price, so that they were not entirely separate option agreements. Belzil J. held ${ }^{124}$ that the purchaser never did abandon or repudiate the agreement and had therefore not precluded himself from claiming the return of the balance of his money.

However on appeal, the Court of Appeal varied this part of the judgment of Belzil J.. The vendor claimed that the option money represented the consideration for "tying up" the land. However the Court continued:

However, by permitting it to be applied on the purchase price it is clear to us that the parties did not assign any value to that "tying up" of this land. Moreover, it is clear from the evidence that the effect of land price inflation would probably be ample satisfaction to the City for the tying up during the option. In the particular circumstances we accept the appellant's request and vary the judg. ment below to this extent. We do this solely because it appears to us that the respondent's justification for retaining the option moneys is not securely founded.

It is not clear from the decision of the Court of Appeal why the payments for both the option and the extension thereof were returned to the purchaser, nor why the vendor's statements as to the "tying up" of the land rendered the contractually-agreed retaining of the option money "unconscionable". No reference was made to any of the principles or approaches set out in the cases already discussed, nor to the question of whether the contract provided for a "penalty". It is to be hoped that in the future this decision is limited to its facts. The Court of Appeal's reasons, quoted above, indicate that this was the intention of the Court.

122. Suprạ n. 118 at 41.

123. (1980) unreported, Q.B. Action No. 96352; affd. with variation (May 1981) unreported, Alta. C.A., Appeal No. 13938 (Edmonton).

124. Id at p. 11 of the Reasons for Judgment of Belzil J. 


\section{STATUTORY RELIEF}

\section{Section 19 of The Judicature Act ${ }^{25}$ is as follows:}

19(1) The Court has jurisdiction and shall grant relief from the consequences of the breach of any covenant or the nonpayment of principal or interest by a mortgagor or purchaser in any case in which the mortgagor or purchaser, his heirs or assigns remedies the breach of covenant or pays all the arrears due under the mortgage or agreement for sale with lawful costs and charges in that behalf,

(a) at any time before a judgment is recovered, or

(b) within such time as by the practice of the Court relief therein could be obtained.

With respect to the granting of relief to a purchaser under an agreement for sale, the courts have clearly distinguished between the right of a mortgagor to redeem under his mortgage and the rights of a purchaser to remedy his breach under an agreement for sale. ${ }^{128}$

In Davidson v. Sharpe, ${ }^{127}$ Anglin J. pointed out that the anomalies introduced by courts of equity in regard to the relations between mortgagor and mortgagee do not exist in regard to vendor and purchaser, and that the judgment or order declaring that on the happening of a certain event, an agreement for sale should be cancelled and at an end meant precisely what it said and not merely that the Plaintiff should thereupon be entitled to have it cancelled and nut an end to. His Lordship explained that, after such an order, a purchaser has no further right to the land, and the court has no jurisdiction to restore him to his former position.

Reference should also be made to Best v. Dussessoye, ${ }^{128}$ where the Manitoba Court of Appeal discussed the difference between a final order for foreclosure of a mortgage and an order cancelling an agreement for sale, and stated that "the reference to the 'equity of redemption' seems to me to be needless. An equity of redemption is not involved in the case."

Similarly, the Supreme Court of British Columbia, in Holmes v. Walker, ${ }^{129}$ has also held that relief is not available to a purchaser of land under an agreement for sale to open up a final order and "redeem". Wilson C.J.S.C. held that the request for an extension of "time to redeem" was not available to purchasers under agreements for sale. His Lordship continued: $:^{130}$

The extraordinary right accorded to a mortgagor to apply for redemption even after a Final Order of Foreclosure is the only instance known to me in English or Canadian law where a judg. ment by the Court which gave it, not granted ex parte, can be set aside or varied, not on the grounds that it was wrongly given, but on the grounds that new circumstances have arisen entitling the mortgagor to relief. Otherwise all judgments or orders of this Court not made ex parte can only be set aside or varied on appeal.

From these decisions, it is clear that once a court has declared or ordered the cancellation or determination of an agreement for sale, the only way in which a purchaser can obtain relief is by way of a successful

125. As amended by S.A. 1971, c. 55 .

126. See Halskov v. Shandruk [1972] 4 W.W.R. 360, where Master Hyndman (at p. 368 ff.) reviewed the previous decisions of the Canadian courts.

127. (1920) 60 S.C.R. 72.

128. [1920] 2 W.W.R. 275, 281.

129. (1968) 66 W.W.R. 182.

130. Id. at 185. 
appeal from that order. In the event there is no such appeal, all the rights of the purchaser are extinguished..$^{131}$

However, s. 19(1) of The Judicature Act does have an important effect on the right to relief in circumstances where the agreement for sale has been determined extra-judicially by the vendor. It is clear from the cases already discussed that the courts of equity would not (except in exceptional circumstances) grant the purchaser specific performance (i.e. relief against "forfeiture" of his interest in the land) in cases where the purchaser had defaulted under the agreement, and particularly in those cases where time had been stated to be of the essence.

Section 19(1)(a) of The Judicature Act states that upon remedy of the default by the purchaser, the court shall grant relief from the consequences of a breach of any covenant or from the consequences of nonpayment by the purchaser "at any time before a judgment is recovered". Where the contract is determined extra-judically, no "judgment" is obtained until the vendor obtains a declaration from the court that the contract has been properly determined. Despite the specific provisions of the contract and the reluctance of the courts of equity to grant specific performance of the agreement where the purchaser has defaulted, s. 19 of The Judicature Act requires the court to grant relief where the breach has been remedied. While courts are opposed to judicial rewriting of parties' contracts, this is in effect what s. 19 compels, and a vendor should be made fully a ware of the possibility of "redemption" under s. 19 at all times during the action prior to the court's judgment.

\section{COSTS}

Although payment of costs (on whatever basis they are ordered by the court or provided by the agreement for sale) is a precondition of the entitlement to relief under s. 19 of The Judicature Act, the vendor may not proceed against an individual purchaser personally for the payment of any moneys required to be paid under the agreement for sale, because of s. 34(17)(a) of The Judicature Act. However, where the agreement for sale was granted to a corporation, s. 35 of The Judicature Act renders s. 34(17) inapplicable so that the vendor may proceed against the purchaser on the personal covenant, subject to the common law.

Section 109 of The Land Titles Act ${ }^{132}$ provides that in the case of an order of foreclosure of a mortgage, the judgment debt is deemed to be extinguished. However s. 109 does not appear to have any application to agreements for sale and reference must be made to the common law. In Standard Trust Co. v.Little, ${ }^{133}$ it was held that the plaintiff was entitled to an order foreclosing the agreement for sale. However the plaintiff was not entitled to enforce the judgment that it had additionally obtained for the instalments still due, except as to costs. In Davidson v. Sharpe ${ }^{134}$ Anglin J. held that when the agreement was cancelled pursuant to the

131. Allegations by the purchaser that he was lulled into a position of security, and that all the facts and circumstances were not presented to the local master (at a hearing of which the purchaser had notice) will not warrant a "reopening": Grayson v. Puckering [1940] 3 W.W.R. 473.

132. R.S.A. 1970 , c. 198.

133. (1915) 8 W.W.R. 1112, 1118.

134. (1920) 60 S.C.R. $72,85$. 
order of the court, the agreement ceased to exist and the foundation for any right of personal recovery from the purchaser (except for costs) was gone. Where the purchaser contests the vendor's right to determine the agreement for sale, the courts seem to be more willing to grant the vendor his costs of suit, ${ }^{135}$ particularly where the position taken by the purchaser is untenable. ${ }^{136}$

In cases where the court grants relief against forfeiture of the purchase moneys or a part thereof, the court will permit a deduction from the moneys to be returned to the purchaser of the costs to which the vendor has been put as a consequence of the purchaser's default, including the costs of legal action. ${ }^{137}$

\section{DISCHARGE OF CAVEAT UNDER THE LAND TITLES ACT}

Another method which should be considered in the removal of a caveat protecting an agreement for sale from the vendor's title is that pursuant to s. 146 of The Land Titles Act. ${ }^{138}$ Section 146(1) states as follows:

In the case of a caveat filed, except a caveat filed by the Registrar as hereinafter provided, the applicant or owner may at any time apply to the court or a judge, by originating notice subject to the Alberta Rules of Court, calling upon the caveator to show cause why his caveat should not be discharged, and upon the hearing of the application the court or judge may make such order in the premises and as to costs as to the court or judge may seem just.

While such an application does not avoid the necessity of giving the appropriate notice, if the same is required by the agreement for sale, ${ }^{139}$ or otherwise determining the agreement for sale in accordance with its provisions, such a procedure offers (at least in theory) an even faster way to remove the encumbrance of the agreement for sale from the vendor's title.

However, the courts will not dispose of such a matter summarily in the event there is any triable issue. In Re Gaar Scott Co. and Giguere, Newlands J. for the Full Court of Saskatchewan stated: ${ }^{140}$

Although this secton gives a very wide discretion to the Judge, it does not, in my opinion, confer upon him the powers of the Supreme Court to decide upon legal or equitable rights between the parties, but only the jurisdiction to decide whether the caveator had any right to file the caveat in question, and if he had at the time of filing such right, whether he had at the time of the application the right to have the caveat continued against such property. If there is a bona fide question of law

135. Moore v.Stewart (1914)7 W.W.R.991,993; Beaton v.Hambicki[1929]1 W.W.R.375, 376.

136. Esson v. Cook (1914) 6 W.W.R. 1080.

137. Yanik v. Conibear [1945] 1 W.W.R. 33, 44, citing Sutherland v. Jones [1922] 2 W.W.R. 1303; George Wimpey Canada $L$ td. v. 105304 Holdings $L t d$, July 1980, unreported, Q.B. Action No. 790309426 (return of purchaser's security deposits ordered, together with order for costs to vendor). However note that on appeal in $A \& M$ Developments $L t d$. v. City of Edmonton (May 1981) unreported, Alta. C.A., Appeal No. 13938 (Edmonton), the Court of Appeal ordered return of the option moneys paid, but further ordered that each side bear its own costs.

138. Supra n. 132.

139. Bezborodka v. Sebenthall [1938] 2 W.W.R. 83.

140. (1909) 12 W.L.R. 245, 246. See also Re Webster and C.P.R. (1907) 6 W.L.R. 384; Re Skill and Thompson (1908) 17 O.L.R. 186; Re Rowand and Strathcona (1907) 5 W.L.R. 450; Re Huber Caveat [1920]2 W.W.R. 16; Re MacCullough and Graham (1912)2 W.W.R.311;Re Wark Caveat (1909) 2 Sask. L.R. 431, 434; McGreevy v. Murray (1912) 1 D.L.R. 285; Re Peychers Caveat [1954] N.Z.L.R. 285; Totten v. Totten (1959) 28 W.W.R. 289, 292; Texas Industries Ltd. v. Northwestern Funding Corporation Ltd. (1977) 4 Alta. L.R. 277; Slater v. Sharma, January 1981, unreported, Q.B. Action No. 800327900 , Funduk M.C.. 
or equity as to the right of the caveator to the estate or interest which he claims under the caveat to be decided, the Supreme Court is the proper place for such question to be disposed of, and the caveat should be continued for sufficient time to allow an action to be brought in which to decide such question.

However, where the matter is clear and where the judge is satisfied beyond all doubt that the caveator nolonger has any interest in the land in respect of which a caveat was filed, then the caveat in question should be discharged. ${ }^{141}$

The types of problems that may arise upon a summary disposition of the matter pursuant to $\mathrm{s.} 146$ of The Land Titles Act are illustrated by the comments of Stuart J. in Re Riddock and Chadwick's Contract: ${ }^{142}$

The purchasers clearly were entitled to file the Caveat at the time they did. Owing to the subsequent default, should I direct its removal? I cannot see how I can take that course in this case, and for this reason. In order to do so I should have to declare the contract rescinded. There would then be several other questions still undecided between the parties. What would become of the money paid? Would Chadwick be entitled to get it back, and could I direct repayment in these proceedings? Would Riddock be entitled to damages, and could I grant them in these proceedings? Again, instead of ordering rescission, should I, as suggested by the purchaser's advocates, treat the purchaser as a mortgagor in default and give him time to redeem? All these questions involve very important principles of law. No argument was made upon them at all practically, and I cannot think it just to attempt to deal with them all while the matter stands in its present form.

In that case his Lordship ordered a trial of the issues, but set out specific directions in order to ensure that such trial took place very promptly. ${ }^{143}$

Other provisions under The Land Titles Act should be considered on an application to remove the caveat. Section 147 provides for an order to ensure security against any damages (including costs) that may be sustained by reason of any disposition of the property being delayed. Section 148 permits (in a manner similar to 5.19 of The Judicature Act) the defaulting purchaser under an agreement for sale to cure the default at any time before the return of the application before the court.

\section{$\mathrm{XV}$. CONCLUSION}

There are, of course, circumstances where, even if the vendor can terminate the agreement for sale against the company, he will not want to do so. In cases where the land value has dropped substantially since the time of sale, the vendor may not want the land back. He may prefer to sue the company on the contract, selling the land by judicial sale either to a third party or to himself, ${ }^{144}$ and to obtain judgment against the company for the deficiency. In this fashion the full amount owing under the agreement for sale may be realized by the vendor.

Extra-judicial determination of the agreement for sale not only provides the vendor who follows the correct procedure with a remedy that is

141. Re Sawyer Massey Co. and Dennis (1907) 7 W.L.R. 272; Fallis v. Balthasar (1912) 2 W.W.R. 132; Marka Holdings Ltd. v. Shores (1978) unreported. S.C. Action No. 106121; Concrete Buildings of New Zealand Ltd. v.Swaysland [1953] N.Z.L.R.997 (caveat based on an illegal contract).

142. (1907) 6 W.L.R. 360, 363.4.

143. See Order of Stuart J.: (1907) 6 W.L.R. $360,366$.

144. On the point of sale to the plaintiff/mortgagee, see the recent decisions of Funduk, M.C. (as yet unreported) in Spenrath Construction Ltd. v. 206763 Holdings Ltd., November 1980, Q.B. Action No. 8003 05412, affd. on appeal by Medhurst J., April 1981; Nordic Mortgage Corp. Ltd. v. Bestlands Development (Albertal Ltd. November 1980. Q.B. Action No. 8003 05741; Heritage Savings \& Trust Company v. Unicorp International In vestments Ltd. January 1981, Q.B. Action No. 800304035. 
quicker than the often-protracted foreclosure proceedings, but also may provide the vendor with a substantial bonus (for which he in fact contracted) without the "risk" of (only) receiving the principal and interest following a completed judicial sale of the land in foreclosure proceedings.

As has been seen, most of the case law on this subject (until recently) stems from cases decided in the 1910s and 1920s. The introduction into The Judicature Act in $1939^{145}$ of the requirement of a judicial sale in all actions upon mortgages and agreements for sale, meant that the possibility of extra-judicial determination all but disappeared. When s. 35 of The Judicature Act was extended in 1964 to except agreements for sale of land to any corporation, ${ }^{148}$ the requirement of judicial sale in actions on agreements for sale to corporations was removed.

Despite the removal of these procedural restraints in 1964, few, if any, cases of extra-judicial determination have until recently found their way into the Alberta courts. However, the last five years have seen a slowly accelerating increase in claims for this form of relief, and although most decisions are made in Chambers and are not reported, it is clear that the remedy of extra-judicial determination is gaining in popularity. Popular though it may be, there still remains the essential requirement that the procedure must be followed correctly. Both the vendor and the purchaser have obligations and rights of which they must be fully aware if they propose successfully to prosecute or defend an action involving the extrajudicial determination of an agreement for sale. 